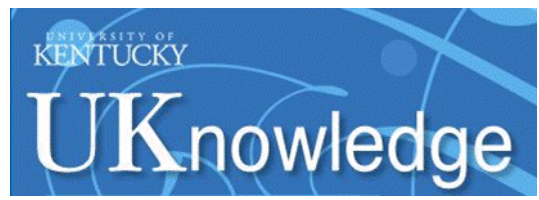

University of Kentucky

UKnowledge

\title{
Safety Concerns, Fear and Precautionary Behavior among College Women: An Exploratory Examination of Two Measures of Residency
}

\author{
Adam J. Pritchard \\ University of Central Florida, adam.pritchard@ucf.edu \\ Carol E. Jordan \\ University of Kentucky, carol.j@uky.edu \\ Pamela Wilcox \\ University of Cincinnati, pamela.wilcox@uc.edu
}

Follow this and additional works at: https://uknowledge.uky.edu/ipsvaw_facpub

Part of the Criminology Commons, Law and Gender Commons, and the Psychology Commons

Right click to open a feedback form in a new tab to let us know how this document benefits you.

\section{Repository Citation}

Pritchard, Adam J.; Jordan, Carol E.; and Wilcox, Pamela, "Safety Concerns, Fear and Precautionary Behavior among College Women: An Exploratory Examination of Two Measures of Residency" (2015). Office for Policy Studies on Violence Against Women Publications. 40.

https://uknowledge.uky.edu/ipsvaw_facpub/40

This Article is brought to you for free and open access by the Policy Studies on Violence Against Women at UKnowledge. It has been accepted for inclusion in Office for Policy Studies on Violence Against Women Publications by an authorized administrator of UKnowledge. For more information, please contact UKnowledge@lsv.uky.edu. 


\section{Safety Concerns, Fear and Precautionary Behavior among College Women: An Exploratory Examination of Two Measures of Residency}

\section{Digital Object Identifier (DOI)}

http://dx.doi.org/10.1057/sj.2012.39

\section{Notes/Citation Information}

Published in Security Journal, v. 28, issue 1, p. 16-38.

(C) 2015 Macmillan Publishers Ltd.

Per the journal publisher: This is a post-peer-review, pre-copyedit version of an article published in Security Journal. The definitive publisher-authenticated version, Pritchard, A. J., Jordan, C. E., \& Wilcox, P. (2015). Safety concerns, fear and precautionary behavior among college women: An exploratory examination of two measures of residency. Security Journal, 28(1), 16-38, is available online at: http://dx.doi.org/10.1057/sj.2012.39 
Pritchard, A.J., Jordan, C.E., \& Wilcox, P. (2013). Safety concerns, fear, and precautionary behavior among college women: An exploratory examination of two measures of residency. Security Journal, doi: $10.1057 /$ sj.2012.39

Safety Concerns, Fear, and Precautionary Behavior among College Women:

An Exploratory Examination of Two Measures of Place

Adam J. Pritchard, University of Kentucky

Carol E. Jordan, University of Kentucky

Pamela Wilcox, University of Cincinnati 


\begin{abstract}
$\underline{\text { Abstract }}$
This study examines the impact of two distinct measures residency on college women's perceptions of safety, fear of crime, and precautionary behaviors within both on-campus and offcampus areas. A student's current residency either on or off-campus and a student's prior residency in a metropolitan, micropolitan, or rural county prior to college are compared across these three aspects of campus safety. Current residency is found to be significantly related to a student's perceptions of safety in off-campus areas around campus, as well as the likelihood of engaging in precautionary behaviors such as avoiding specific locations on campus or carrying or keeping items (e.g., weapons) for protection. Prior residency, on the other hand, was not found to impact perceptions of safety, fear of crime, or precautionary behaviors.
\end{abstract}

\title{
KEYWORDS:
}

college women, fear of crime, safety precautions, place, violence against women 
"Safety Concerns, Fear, and Precautionary Behavior among College Women: An Exploratory Examination of Two Measures of Place"

Since the 1980's, researchers have paid much attention to issues of fear of crime in the United States. Researchers have demonstrated correlations between numerous social phenomena and levels of fear of crime in the United States, including the inflationary role of news media (Altheide, 2002), the effects of gender and age (Fisher \& May, 2009; LaGrange \& Ferraro, 1989; May \& Dunaway, 2000; Warr, 1984), and the interaction between fear of sexual victimization and fear of other crimes (Ferraro, 1995; Fisher \& Sloan, 2003; May, 2001; Melde, 2009; Warr, 1985; Wilcox, Jordan, \& Pritchard, 2006). In particular, substantial research has investigated the prevalence of fear of crime among college women. This is an important line of inquiry within the literature on fear, since college women experience relatively high rates of sexual victimization risk within the unique spatial and social context of a college campus (e.g., Fisher \& Sloan, 2003; Lane, Gover, \& Dahod, 2009; Rader \& Cossman, 2011; Wilcox, et al., 2006; Wilcox, Jordan, \& Pritchard, 2007; Woolnough, 2009).

The importance of "place" in understanding fear of crime has received a good deal of attention. Researchers have examined characteristics of both the surrounding physical environments and the social spaces which contribute to perceptions of safety and risk (Benbenishty \& Astor, 2005; Fisher \& Nasar, 1995; Kruger, Hutchinson, Monroe, Reischl, \& Morrel-Samuels, 2007; Pain, 2000; Swartz, Reyns, Henson, \& Wilcox, 2011; Tillyer, Fisher, \& Wilcox, 2011; Wilcox, Quisenberry, \& Jones, 2003). Some scholars have also drawn connections between fear of crime and community context (Benbenishty \& Astor, 2005; Jackson, 2004; LaGrange, Ferraro, \& Supancic, 1992; McGarrell, Giacomazzi, \& Thurman, 1997; Taylor, 2001), including fear of crime effects related to patterns of rural-to-urban migration (Hunter, 
Krannich, \& Smith, 2002; Kennedy \& Krahn, 1984). Research also has examined the effects of various place-related variables on women's perceptions of safety on campus, but few studies have directly considered students' current and prior residential experiences as possible influences on their perception of safety within a place.

The present study seeks to augment this area of the literature by distinguishing perceptions of safety and victimization risk in on-campus and off-campus places among college women across two measures of residency: current residence while a university student (e.g., living on-campus or off-campus), and residency in different types of communities prior to attending college (e.g., coming from a metropolitan, micropolitan, or rural county). These variables will be used to distinguish whether proximal or distal residency experiences (or both) impacts a woman's concern for safety, fear of crime, and precautionary behavior for on-campus or off-campus places while attending college.

\section{Literature Review}

Fear of Crime on College Campuses

Studies examining fear of crime among college students have highlighted substantial sex differences in fear of crime (Hilinski, 2009; Lane, et al., 2009; Rader \& Cossman, 2011). This research builds upon a larger body of fear of crime research which robustly supports sex as a key predictor of fear of crime in general (e.g., Ferraro, 1995, 1996; LaGrange \& Ferraro, 1989; Schafer, Huebner, \& Bynum, 2006; Warr, 1984, 2000). In both college and community samples, the most common distinction between men and women on fear of crime relates to differences 
between fear of victimization and perception of risk. Men have been found to express higher levels of fear of criminal assault (e.g., robbery) when they perceive a the risk of victimization to be more likely, while higher levels of fear among women are best predicted by her fear of being sexually assaulted (Ferraro, 1996; Lane, et al., 2009; Wilcox Rountree \& Land, 1996).

The extant literature also finds that college women take precautionary actions in response to their fear of crime. Research has found that college women with high levels of fear of crime may limit their activities, interactions, or movements around campus (Hickman \& Muehlenhard, 1997; Keane, 1998; Wilcox, et al., 2007; Woolnough, 2009). A number of studies have included measures of avoidance behaviors in conjunction with fear of sexual assault and other crimes with mixed results (Fisher \& Sloan, 2003; Hilinski, 2009; Lee \& Hilinski-Rosick, forthcoming; Wilcox, et al., 2007). Fear of stranger sexual assault has also been identified as a significant influence on a college woman's increased likelihood of carrying a weapon or other selfprotective item (Hickman \& Muehlenhard, 1997; Wilcox, et al., 2007).

Research also shows that women experience and perceive certain types of offenses differently than do men. Studies investigating fear of crime among women in general, and specifically among college women have examined how the fear of sexual assault and the fear of stalking shape women's perceptions of safety and their risk of victimization.

One of the most robust influences on women's fear of crime is the fear of sexual assault. The "shadow of sexual assault hypothesis" (Ferraro, 1995, 1996; Wilcox, et al., 2006) postulates that the possibility of co-occurring stranger sexual assault increases fear of other violent crimes among women. This hypothesis has been put forward as an explanation for women's higher levels of fear of crime in general, and has found empirical support among college samples in various multidimensional constructs that control for differences across crime type and victim- 
offender relationship (Fisher \& Sloan, 2003; Hilinski, 2009, 2010; Hughes, Marshall, \& Sherrill, 2003; Lane, et al., 2009; Wilcox, et al., 2006, 2007). For college women, research suggests that fear of stranger sexual assault may be influential to both cognitive perceptions of safety and emotional fear of crime, given the ubiquitous influence that fear of stranger sexual assault exhibits across most measures examined in previous studies.

Research on stalking among college women also reveals distinctive effects on fear and safety perceptions. For instance, college women who self-defined an experience as stalking expressed higher levels of fear than women who experienced similar behaviors but did not define them as stalking (Jordan, Wilcox, \& Pritchard, 2007). In the National Violence Against Women Survey, women who reported stalking were more likely to engage in precautionary behaviors such as carrying items for protection (Tjaden \& Thoennes, 1998). Hughes, Marshall, and Sherrill (2003) found that fear of stalking was increased by fear of sexual victimization, but also that context of the victimization mattered. For instance, using the term "Peeping Tom" versus "prowler" resulted in less fear, which the authors suggest may differ because women may presume that the term prowler connotes intent to commit further acts of violence (p.43). Other research suggests that college women who had experienced prior sexual victimization were more likely to experience stalking victimization (Buhi, Clayton, \& Surrency, 2009; Fisher, Cullen, \& Turner, 2002). Research suggests that when a stalking is by an intimate partner, the associated violence is more several and threats are more likely to be carried out (Fisher, et al., 2002; Logan, Walker, Jordan, \& Leukefeld, 2007; Palarea, Zona, Lane, \& Langhinrichsen-Rohling, 1999; Tjaden \& Thoennes, 1998). Other research suggests that an intimate relationship with the offender may even decrease acknowledgement of certain behaviors as stalking (Phillips, Quirk, Rosenfeld, \& O’Connor, 2004). For stalking, as with sexual assault, these studies suggest that 
victim-offender relationship may impact a woman's reaction to stalking, but that in general stalking appears to increase a woman's behavioral safety precautions as well as her risk for intimate victimization.

\section{Current and Prior Residency, Community Type, and Response to Crime}

Relatively few studies have considered a female college student's residency experiences either while at college or before attending college - as possible influences on her place-specific perceptions of safety, fear, or precautionary behavior, though there are some exceptions. For example, Woolnough (2009) found that women who lived off-campus at one large, urban university were significantly more likely to carry a weapon than women living on-campus. Fisher and Sloan (2003) examined fear of sexual assault among college women across multiple universities, and found that living on-campus was positively associated more fear of rape when controlling for age (over 25 years old), while the geographic location of the campus (e.g., urban, suburban, rural) was not a significant influence. Though an effect of prior residency was hypothesized by Woolnough (2009), his study did not find the urban, suburban, or rural character of a student's hometown to be a significant influence on fear or self-protective strategies.

A woman's racial and place-specific background may also be important factors in shaping her response to crime. Research has repeatedly found that race and ethnicity impact women's response to victimization with respect to help-seeking strategies (Amar, Bess, \& Stockbridge, 2010; Campbell et al., 2008; Clauss-Ehlers, 2008; El-Khoury et al., 2004; Lipsky \& Caetano, 2007; Lipsky, Caetano, Field, \& Larkin, 2006; Nicolaidis et al., 2010; Sabina, Cuevas, \& Schally, 2011). While not specifically examining college women, limited research on place of 
origin and fear of crime suggests that where a woman is from may influence her fear of crime and perceptions of victimization risk after migration. Kennedy and Krahn (1984) found that for women living in an urban area, the place they grew up was the strongest predictor of fear of crime. They found that an urban background was associated with higher fear of crime, while a rural background was associated with lower fear of crime. The authors suggest that this may reflect the use of fear-mitigating strategies common to rural communities, such as getting to know one's neighbors. Other research supports the contention that rural women actively use social networks and informal neighborhood contacts to reduce fear of crime (Donnermeyer \& Mullen, 1987; Hunter, et al., 2002). Since coming to a large state university is also a migration from a small community into a large urban area, it is reasonable to suspect that college women from rural backgrounds may exhibit similar patterns.

A qualitative study on rural women's health behaviors, for example, noted references to the way rural culture impacts help-seeking and supportive behaviors, reporting that "because of the familiarity of rural residents with one another, they are often aware of particular needs and lack of resources" (Leipert \& George, 2008, p. 215). While personal networks appear to affect help-seeking, it is unclear whether or not college women from small town or rural backgrounds perceive their risk of victimization differently when offenders are known or versus unknown. It is possible women form large urban areas respond differently to the fear of sexual assault than do women from rural places, given different patterns of exposure to victimization in their community of origin. National level data suggest that people in rural places experience lower rates of violent victimization (e.g., Duhart, 2000), however other research challenges the reportedly low rates of sexual victimization in rural places owing to privacy concerns in small communities (Ruback \& Menard, 2001). Recent research finds that women living in rural 
communities may even experience more stalking than other women (Fisher, Daigle, \& Cullen, 2010). Therefore, a woman's geographic background may shape how the possibilities of sexual assault, intimate stalking, or other perceived risk of violence influence her concern for personal safety. It is unclear whether or not these victimization experiences in previous residential places carry over to women's perceptions of fear and safety in other places, such as a college campus.

\section{Summary: Gaps in the Literature}

Previous research has not fully considered the effects of a college woman's current and prior residency experiences on her fear of crime, safety perceptions, and behavioral safety strategies. In particular, residency variables have not been examined as potential influences on a woman's experience of place-based fears, such as differences between safety perceptions or precautions in on-campus and off-campus places. Previous research on women's fear of crime at college examined the effects on- and off-campus residency on concerns for safety and precautionary behaviors (e.g., carrying a weapon), but did not disaggregate perceptions of safety across on-campus versus nearby off-campus places (Wilcox, et al., 2007; Woolnough, 2009). Addressing this gap will help us better understand the relationship between current residency (e.g., living on-campus or off-campus) and concern for safety in specific places. Since concern for safety in particular places is important for understanding how women perceive the campus, it is important to identify whether any differences in safety concerns by a student's current residence generalize to all areas (e.g., on- and off-campus) or are specific to a certain place in terms of overall safety perception, fear of specific forms of victimization, and the precautionary behaviors taken to mitigate this fear. 
Also, no studies have examined whether or not a college woman's prior residency in large metropolitan areas, micropolitan cities, or rural communities influences a woman's perception of safety either on-campus or in off-campus urban places. Most previous research has only considered the geographic campus location (urban, suburban, rural) as a contextualizing crime variable (e.g., Fisher, Sloan, Cullen, \& Lu, 1998) rather than a potential influence on safety perceptions, and few studies ask students about their place-specific background experiences. Notably, Woolnough (2009) controlled for students' type of hometown (urban, suburban, rural) but found no significant effects of safety perceptions of precautionary behaviors in a sample where $70.4 \%$ of students reported coming from a suburban hometown. However, it remains unclear whether or not college women's concern for safety, particularly in off-campus areas, is at all related to the type of community she lived in prior to attending college. It is conceivable that moving from a small city or a rural community into a large metropolitan urban area for the purposes of attending college could influence a college woman's perceptions of crime and safety. Previous literature suggests that women moving from rural to urban areas have lower fear of crime, but this has not been systematically examined in the college context. Prior residency experiences may also influence perceptions of specific crime types committed by specific offenders. Examining current and prior residency will help to clarify the role residency experiences play in perceptions of safety within places, and could guide college administrators in developing safety interventions to address concerns for safety either through information tailored to students' current residential location, to students' geographic background, or to both.

\section{The Present Study}


The present study examines two measures of residency and their effects on place-specific concern for safety, fear of specific crimes by specific offender types, and safety-related precautionary behaviors. Residency experiences may affect a college woman's perceptions of place in at least two ways. Residency may have proximal effects, such that a college woman's immediate living environment (e.g., living on-campus or off-campus) directly influences her concerns for safety, fear of victimization, and precautionary behaviors. Residency may also have distal effects, meaning that a woman's prior residency experiences within other types of places (e.g., metropolitan areas, micropolitan areas, or small rural communities) may affect how she evaluates her present environment for safety. Nonetheless, as reviewed above, few studies explicitly test the influence of residency on college women's safety perceptions, fear of crime, and safety behavior. The present study examines current and prior residency experiences across these three domains of campus safety measures.

\section{$\underline{\text { Methods }}$}

\section{Sample}

This study investigates college women's fear of crime and response to victimization using survey data collected from college women at a large, Southern university. The university is a land-grant institution with an enrollment of around 30,000 students located in a metropolitan county with a population of around 280,000 residents. The purpose of the survey was to measure female students' perceptions of safety and victimization risk on campus, estimate the prevalence of several types of violence against women on campus (i.e., sexual, physical, and stalking 
victimization), and understand the details of the most recent victimization experience of each type including victim-offender relationship, help-seeking, reporting, and service utilization behaviors.

The surveys were conducted using computer-assisted telephone interviews (CATI) by an independent survey research agency in Spring 2007. The target sample size for the study was 2,000 subjects, for which a university-provided random sample of 10,000 phone numbers from student records was given to the interview firm. Of these, 9,433 numbers were dialed resulting in 7,550 valid contacts which were called up to a maximum of 20 times until subject completed the survey, refused, or the target sample size was reached. Ultimately, 3,481 subjects were administered the survey screening questions before the targeted quota 2,000 valid surveys was reached. The survey's cooperation rate was $69.2 \%$. The overall response rate was $34.6 \%$. The final sample consisted of 2,001 completed interviews.

The student population in the survey sample was comparable to the reported population of the university on available measures. Confidence intervals $(\mathrm{p}=.05)$ placed sample proportions within range of known population data for full-time enrollment (83.4\%), percent of White students (84.2\%), and percent of undergraduate students (69.9\%) in the sample. There were far more seniors and far fewer freshmen represented in the sample then were expected from university-wide data, however with any university sample it is reasonable to expect some discrepancies between fall enrollment numbers and spring retention, particularly for first-year students. However, it is also possible that upperclassmen were more willing to participate in the survey. For subsequent analysis, data have been weighted to correct for academic class based on population parameters. With this adjustment, the sample data appear to be sufficiently representative of the university population for analysis and generalization. 


\section{Measures}

This study investigates college women's perceptions of safety within two different places, on-campus areas and nearby off-campus areas, by controlling for a student's current and prior residency. Current residency was measured by asking students if they lived in campus dorms, sorority housing, or university-owned apartments; or if they lived in an off-campus apartment or house, or with their parents. A dichotomous variable was then created to indicate whether a student lived on-campus or off-campus. Prior residency was measured by asking students what county they lived in prior to coming to the university. This measure was chosen as a slight refinement over type of hometown (e.g., Woolnough, 2009) so that students would: 1) not be counted upon to classify the demographic character of their previous residence correctly, and 2) would report their immediate prior residence rather than a hometown in which they may have been born but did not recently live. Recording the exact county also allowed researchers to go beyond a simple urban/suburban/rural categories and instead use definitions created by the Office of Management and Budget (OMB) and the USDA's Economic Research Service (ERS) for the purposes of understanding communities' social and economic diversity. The 2003 Urban Influence Codes were used to categorize students' prior residences into meaningful subgroups. The Urban Influence Codes group U.S. counties into one of 12 categories based on urban population centers and adjacency to urban areas. A three-category sub-grouping defined by ERS was used for this analysis. The three major categories are: metropolitan counties (codes 1-2), micropolitan counties (codes 3, 5, and 8), and noncore counties (codes 4, 6, 7, 9-12). Described simplistically, urbanized areas of 50,000 residents or more are considered metropolitan, while 
urbanized areas of 10,000 residents or more are considered micropolitan. The designation "noncore" refers to counties that lack an urban center of more than 10,000 residents (see http://www.ers.usda.gov/Briefing/rurality/UrbanInf/).

Perceptions of safety were measured both generally and specifically. For example, women were asked about concern for personal safety with the question "How safe do you think you are from crime on [university]'s campus?” measured on a four-point scale ( $1=$ "Very safe", $2=$ "Somewhat safe", $3=$ "Somewhat unsafe", 4= "Very unsafe"). The same question was asked regarding concern for safety in "residences, neighborhoods, or other areas around campus." Additionally, students were asked to make a direct comparison between their feelings of safety prior to and since coming to college. Students were given two options to the question: "In general, do you feel safer or less safe since coming to [university]?” Several students who refused to endorse either "safer" or "less safe" provided the answer "same/just as safe" which was intentionally recorded by the interviewer, but not offered as a choice unless the subject volunteered this option.

Fear of crime was measured using six survey items that addressed combinations of subjects' worries about sexual, physical, or stalking victimization and their concern that these offenses would be perpetrated against them by either someone they know or a stranger. Survey respondents were asked all six questions in the following format "There has been some discussion in the news recently about stalking. How worried are you personally about being stalked by someone you know?" and also utilized a four-point scale (1="very worried", 2="somewhat worried", 3="just a little worried", 4="not really worried") which was reversecoded for analysis so that a higher value would indicate more worry. The six variations of this question addressed stalking by a known offender, stalking by a stranger, sexual assault by a 
known offender, sexual assault by a stranger, physical assault by a known offender, and physical assault by a stranger. This coding allowed researchers to explore possible relationships between residency and fear of crime across victimization type and offender type.

Precautionary safety behaviors were measured by asking students whether or not they intentionally avoided places on campus out of concern for their safety, or if they kept or carried any item for protection.

Hypotheses and Analysis

The overall objective of this study is to explore the question of whether or not an undergraduate college woman's current residency (living on- or off-campus) or her prior residency (in a metropolitan, micropolitan, or noncore county) impacts her concern for safety in on-campus or off-campus places, her fear of victimization, or her use of precautionary behaviors. Specifically, our study investigates the following:

1) Does a person's experience of residency, proximally as current residence or distally as prior residence, impact a woman's concern for safety in either on-campus or offcampus places at college?

We hypothesize that living off-campus will increase concerns for safety, and a nonmetropolitan place of prior residence will be associated with less concern for safety at the university.

2) Does residency impact fear of specific crime-type and offender combinations? 
We hypothesize that students living off-campus will express higher fear of stranger perpetrators. We expect students previously residing in micropolitan and noncore counties to have less fear of known perpetrators than their metropolitan peers.

3) Does residency affect the type of precautionary behaviors engaged in by female students out of concern for their safety?

We hypothesize that students living off-campus will be more likely to carry or keep an item for personal protection, while students living on-campus will be more likely to avoid specific locations on campus. We hypothesize that students from metropolitan areas will be more likely to carry protective items than students from smaller communities.

In order to improve the validity of our prior residency measure, several considerations were made. Initially 1,881 students reported a valid U.S. county of previous residence. Students who reported their previous residence as the same county as the university $(n=316)$ were removed, since comparison against a previous place of residence was a key element in this analysis. Controlling for students who previously lived in the same county also improved the validity of our measure of current residency by eliminating students who lived off-campus but in their parents' home. Additionally, 437 graduate students were removed from the sample because it was unclear whether or not their previous county of residence was a hometown, or simply the location a previous college or university. The final sample consisted of 1,124 undergraduate females.

$\underline{\text { Results }}$ 
Of the female students in our sample with valid responses, $45.7 \%$ lived on-campus. Students from metropolitan counties comprised $70.1 \%$ of the sample, micropolitan students accounted for $14.6 \%$, and $15.2 \%$ were from noncore counties according the Urban Influence Code for their previous county of residence. At least one form of victimization since coming to college was reported by $36.6 \%$ of the sample, with $21.2 \%$ experiencing sexual victimization (including 5.2\% who reported being raped), 11.7\% experiencing physical victimization, and 16.3\% experiencing stalking. Overall, $55.1 \%$ of students reported feeling as safe or safer since coming to the university. Most students were white (85.7\%), Black students comprised 7.6\% of the sample, Asian students accounted for $2.2 \%$, and $3.2 \%$ were mixed race. Only $2.4 \%$ of students reported having a Hispanic background. The majority of students were currently involved in a romantic relationship (59.2\%), while 32.0\% reported consuming alcohol at least once per week. Many students reported engaging in precautionary behaviors such as avoiding specific places on campus out of concern for safety (78.9\%) and carrying or keeping some item at home for protection (52.0\%).

Variables of interest in this study include place of current and prior residency. Students living on-campus versus those living off-campus significantly differed on a number of study variables (Table 1). Notable differences by current residence include higher rates of alcohol use and victimization for students living off-campus. Students were more likely to live on-campus early in their time at college (freshman, sophomore) and more likely to live off-campus as upperclassmen (junior, senior). In contrast, only race and alcohol use significantly differ across any of the three categories of prior residence (Table 2).

[Insert Table 1 about here] 
[Insert Table 2 about here]

\section{Concern for Safety}

Our first research question asks: does a person's experience of residency, proximally as current residence or distally as prior residence, impact a woman's concern for safety in either oncampus or off-campus places at college? On the four-point scale asking how safe do you think you are from crime, college women regardless of current residency expressed a significantly higher mean level of safety concern when considering "residences, neighborhoods, or other areas around [university]'s campus" compared to "on [university]'s campus." Overall, students expressed significantly more concern for safety in off-campus areas around campus compared to on-campus areas (mean: 2.11 vs. 1.76, $\mathrm{t}=13.08, \mathrm{p}<.000$ ). One-way ANOVA indicates that women who lived on-campus expressed significantly higher mean levels of concern for safety than women who lived off-campus when considering both on-campus areas (mean: 1.81 vs. 1.70, $\mathrm{F}=9.297, \mathrm{p}=.002$ ) and off-campus areas (mean: 2.21 vs. 2.00, $\mathrm{F}=29.100, \mathrm{p}<.000$ ).

Prior residence, categorized using the Urban Influence Codes, did not significantly impact concern for safety on- or off-campus. In a one-way ANOVA, prior residence was not significantly related to mean level of concern about safety on-campus (mean: metro, 1.76, micro, 1.81, noncore, 170; $\mathrm{F}(2)=1.431, \mathrm{p}=.240$ ) or off-campus (mean: metro, 2.11, micro, 2.15, noncore, 2.13; $F(2)=.266, \mathrm{p}=.766$ ). Prior residence was also not significantly associated with whether or not a student lived on-campus or off-campus, and mean levels of concern for safety between students from different categories of prior residency did not significantly vary across current 
residency. Likewise, there were no significant differences with respect to prior residency on the question directly asking "do you feel safer or less safe since coming to [the university]?" even if controlling for current residency.

Given that several variables significantly differed between on-campus versus off-campus residents (see Table 1), it was necessary to examine the relationships between current residence, prior residence, and concern for safety in specific places using multivariate models in order to control for these variables. The concern for safety measures are ordinal variables, however preliminary analysis revealed that the proportional odds assumption would be violated due to an extremely small number of subjects endorsing the "very unsafe" category. The concern for safety dependent variables were instead re-coded into dichotomous variables where 1=Safe ("very safe" and "somewhat safe"), and 2=Unsafe ("somewhat unsafe" and "very unsafe"), allowing us to use binary logistic regression as a more robust alternative. Model variables were first examined using bivariate correlations which did not reveal any highly correlated variables. Independent variables included in the final models were examined for multicollinearity, and all variables had tolerances between .456 and .983, indicating no serious collinearity between predictors (generally indicated by tolerances around or below .100). Final models also passed the Hosmer \& Lemeshow goodness-of-fit test. $^{1}$

Neither measure of residency significantly affected the odds of a female student feeling unsafe on-campus (Table 3). However, concern for safety in nearby off-campus areas was significantly related to a student's current residence. The odds ratio for living on-campus was 1.743, indicating that the odds of a female student feeling unsafe in off-campus areas was $74 \%$ higher for students living on-campus compared to those living off-campus. In both models, prior

\footnotetext{
${ }^{1}$ Fear of stranger sexual assault was not included in the either concern for safety model, since it had a detrimental effect on model fit for concern for safety off-campus.
} 
victimization experiences had a significant, negative effect on the odds of feeling unsafe. The betas for academic class standing (using freshmen as a reference group) were all negative and in some cases significant, suggesting that general concern for safety may decrease somewhat over time in college.

[Insert Table 3 about here]

Fear of Crime

Our second research question asks: does residency impact fear of specific crime-type and offender combinations? Previous research on fear of crime (e.g., Wilcox, et al., 2006) suggests that victim-offender relationship and type of crime strongly influence fear of crime among college women. This study builds up this previous work by also controlling for the possible influences of current and prior residency in shaping crime- and offender-specific fear of crime. Mean levels of fear of crime, measured by a four-point scale (1-4), revealed significant mean differences across current residency when compared across specific crime type-offender configurations (Figure 1). Overall levels of fear of specific forms of victimization were extremely low, with means less than 2 on a 1-4 scale for all combinations except fear of stranger sexual assault, and stranger physical assault. In fact, fear of victimization by a stranger offender was significantly higher than fear of victimization by acquaintances within each of the three crime types examined: stalking, sexual assault, and physical assault.

[Insert Figure 1 about here]

With respect to current residency, ANOVA reveals significant differences for all three crime types between women living on-campus and off-campus with respect to fear of 
victimization by known offenders. Women living on-campus were significantly more worried about being victimized by an acquaintance than women living off-campus for the crimes of stalking $(\mathrm{F}(1)=7.368, \mathrm{p}=.007)$, sexual assault $(\mathrm{F}(1)=4.855, \mathrm{p}=.028)$, and physical assault $(\mathrm{F}(1)=4.893, \mathrm{p}=.027)$. There were no differences between on- and off-campus residents on any measure of stranger victimization. Among all subjects, fear of stranger sexual assault was significantly higher than all other crime type-offender combinations, a finding consistent with previous literature.

With respect to prior residency, mean fear of stalking, sexual assault, and physical assault did not significantly differ by prior residency category, even when controlling for victimoffender relationship (Figure 2). ANOVA revealed no significant differences by prior residence. It is notable that micropolitan areas almost always had lower levels of fear across crime type and victim-offender relationship, though these levels were not significantly lower than either metropolitan or noncore students.

[Insert Figure 2 about here]

As with the concern for safety analysis above, multivariate models were employed to control for additional influences on fear of specific crime-offender combinations. Preliminary ordinal logistic regression models violated regression assumptions, so fear of crime variables were re-coded into 0,1 binary variables, with 1 indicating "somewhat or very worried" about a given crime-offender combination. Six binary logistic regression models were created to examine the likelihood of a female student experiencing high levels of fear of specific forms victimization (Table 4). In addition to other independent variables, high fear of stranger sexual assault was controlled for in the models for stalking and physical assault. This variable was 
included in order to control for the "shadow of stranger sexual assault" effect found to be significant in previous literature.

[Insert Table 4 about here]

Binary logistic regression models found that neither current nor prior residency significantly influenced whether or not a student was "somewhat or very worried" about any of the six crime-offender combinations examined. However race, prior victimization, and fear of stranger sexual assault were significant in most models. The odds of a minority student expressing high fear of stalking by either a known person or a stranger were approximately double that of white students. High fear of stranger sexual assault significantly increased the odds of a female student expressing high fear of stalking by a factor of 3.48 for known offenders and 5.46 for strangers. Prior victimization experiences at college significantly increased the odds of fearing stalking by a known person (OR: 2.26) and was near significant $(\mathrm{p}=.053)$ for fear of stalking by a stranger (OR: 1.394). Only prior victimization experiences were significantly related to concern for sexual assault by either a known person or a stranger, and in both cases prior victimization was associated with significant increases in the odds of expressing high levels of fear of sexual assault. Prior victimization increased the odds of fearing sexual assault by a known person by a factor of 2.52, but only increased odds of fearing of stranger sexual assault by a factor of 1.56. Finally, the odds of having high fear of physical assault by a known person and by a stranger were significantly increased by having high fear of stranger sexual assault (OR: 5.870 and 18.126, respectively). This is consistent with previous literature, which finds that fear of stranger sexual assault is highly correlated with other types of assault, in particular by stranger offenders. Odds of having high fear of physical assault by a known perpetrator were significantly 
increased for minority women (OR: 2.046) and those experiencing prior victimization in college (OR: 2.029).

\section{Precautionary Behaviors}

Our third research question asked: does residency affect the type of precautionary behaviors engaged in by female students out of concern for their safety? Precautionary behaviors were examined using binary logistic regression models to examine how current or prior residency might shape the odds of a female student: 1) carrying or keeping an item for protection, and 2) avoiding locations on-campus out of concern for safety. Like the above analyses, these models included the following independent variables: current residence, prior residence, and the control variables of race, romantic involvement, alcohol use, victimization at college, and academic class. In addition, these models also controlled for concern for safety oncampus and off-campus, and fear of stranger sexual assault as potential predictors (Table 5).

[Insert Table 5 about here]

A student's current residence was significantly related to both forms of precautionary behavior, while no prior residency category significantly impacted the odds of engaging in either of these forms of self-protection. A female student's odds of carrying or keeping some object for protection were significantly increased by currently being in a romantic relationship (OR=1.486) and by having high levels of fear of sexual assault $(\mathrm{OR}=1.476)$, while the odds were significantly decreased by living on-campus (OR=.700). The odds of avoiding places on-campus out of concern for safety was significantly increased by living on-campus (OR=2.391), high fear of stranger sexual assault ( $\mathrm{OR}=1.935)$, increased concern for safety on-campus $(\mathrm{OR}=1.789)$, 
increased concern for safety off-campus $(\mathrm{OR}=1.712)$, and junior $(\mathrm{OR}=2.026)$ or senior $(\mathrm{OR}=1.705)$ class standing. All academic classes had positive coefficients compared against freshman class standing, but only junior and senior were significant in the model for avoiding places on campus.

\section{$\underline{\text { Discussion }}$}

This study asked three questions exploring whether or not a female student's reactions to crime and safety are affected by her residency experiences, either proximally by where she currently lives, or distally by considering differences in character of a student's prior residential community. This study considered residency in the contexts of place-specific concern for safety, fear of specific forms of victimization by specific types of offenders, and use of certain safety precautions. These two measures of residency have very different implications for targeting safety interventions to college women, namely whether a student's prior residence or her current residence has a bigger influence on how she perceives and mitigates her risk of victimization while at the university.

Our study first examined the question: does a person's experience of residency, proximally as current residence or distally as prior residence, impact a woman's concern for safety in either on-campus or off-campus places at college? Direct comparisons find that college women in our sample expressed significantly higher concern for safety in nearby off-campus areas than on-campus, regardless of where students currently reside. Controlling for other variables, current residence did not impact women's concern for safety on-campus, however current residence did impact concern for safety in off-campus areas. Living on-campus 
significantly increased the odds that a female student worried about her safety in nearby offcampus areas. It is possible that living off-campus mitigates the fear of off-campus places as a student establishes a familiar routine in these specific areas. If students who choose to live offcampus did so because they were generally less fearful, we would expect concern for safety oncampus to also be lower for these off-campus residents. This was not the case. Therefore, it seems that location of current residency is itself directly important.

Second, our study asked: does residency impact fear of specific crime-type and offender combinations? This analysis examined the relationship between type of victimization (sexual, physical, stalking) and offender (stranger, known person) while controlling for our two residency variables. One important finding in this study is that the fear of specific forms of victimization by specific offenders is, in general, extremely low. That is, with the exceptions of stranger sexual and physical assault, most of these female students expressed very low levels of fear. Nevertheless, we hypothesized that off-campus residents would experience higher fear of stranger offenders, since they would perceive a greater likelihood of exposure to potential stranger perpetrators. The data, however, show that instead of increased fear of stranger perpetration, living off-campus was only associated with significantly lower fear of acquaintance perpetration when compared to on-campus residents. The question of why students living offcampus would express less fear of victimization by a known perpetrator should be investigated in future research, especially in light of the fact that students living off-campus experienced higher rates of victimization, and most often by people they knew. Multivariate models showed that other factors, namely race, prior victimization, and fear of stranger sexual assault were more important than current residence in predicting fears of specific forms of victimization. 
Finally, we asked: does residency affect the type of precautionary behaviors engaged in by female students out of concern for their safety? We examined two precautionary behaviors: carrying or keeping an item at home for protection, and avoiding places on campus out of concern for safety. Consistent with prior literature, living off-campus increased the odds that a student would carry or keep in her home something for protection. Also, being involved in a romantic relationship increased the odds of carrying or keeping safety objects in the home. It is unclear why this particular item is significant, however it may be possible that male romantic partners encourage this specific form of safety behavior. Another possibility is that simply having a boyfriend may be seen by some women as protective from crime, and thus being in a committed relationship may be part of multiple strategies used to increase feelings of safety.

Avoiding specific locations on-campus out of concern for safety is also significantly related to student's current residency, with on-campus students having more than twice the odds of engaging in this particular precautionary behavior. This behavior is also significantly associated with general concern for safety both on-campus and off-campus, as well as positively associated with higher academic standing. Consistent with previous literature, fear of stranger sexual assault significantly increased the odds of engaging in both forms of precautionary behavior measured. High fear of stranger sexual assault increased the odds of avoiding places on campus by $94 \%$ and increased the odds of carrying a protective item by only $48 \%$. These findings suggest that women are more likely to utilize avoidance rather than resistance strategies in response to fear of sexual assault. Future research should examine in greater detail the relationship between fear of sexual assault and different types of precautionary strategies in the context of sexual victimization, especially given that place avoidance strategies may not be 
appropriate for the majority of sexual assault incidents which are usually perpetrated by acquaintances.

A notable finding throughout this dataset is that concern for safety, fear of victimization, and precautionary behaviors are supportive of a "stranger danger" bias in campus safety perception. For instance, students who had been victimized since coming to college were less likely to rate the campus as unsafe. This apparently counterintuitive result can again be reconciled with the fact that students were far more likely to be victimized by a known offender rather than a stranger. A good deal of the extant literature suggests that fear of strangers, and particularly stranger sexual assault, strongly influences general safety concerns for women. Significantly higher mean worry about stranger sexual assault and stranger physical assault found in the fear of crime section of this study certainly support such an interpretation. While it is also possible that prior victimization may increase safety precautions (and thus mitigate safety concerns), the fact that prior victimization was not associated with either of the precautionary behaviors in this study suggests that this second explanation is unlikely. Prior victimization at college was only associated with significant increases in the odds of expressing high fear of crimes perpetrated by known offenders. These findings corroborate the "shadow of sexual assault" hypothesis in that prior victimization seems to only impact worry about perpetration by known persons, while fear of stranger sexual assault has a more ubiquitous effect.

Finally, no hypotheses regarding prior residency were supported. Type of prior residency was not directly significant in any models, nor does it influence whether or not a student chooses to live on- or off-campus. This result is consistent with Woolnough's finding that hometown was not a significant factor in fear of crime or safety behaviors (Woolnough, 2009). The use of the Urban Influence Codes rather than self-reported urban, suburban, or rural hometown is, in our 
view, a slight improvement in the quality of a measure of prior residency, nonetheless yielding similar results. It is also possible that broad, community-level measures are not the best way to understand how a person's geographic background shapes their understanding of new places. Since previous literature suggests that prior residency shapes help-seeking in response to victimization, it is possible that place prior residency simply does not significantly shape either of the two precautionary behaviors examined, but may impact how a woman responds to an actual victimization experience. However, the present study suggests that with regard to role of prior residency in perceptions of crime and safety, students may quickly adapt to their new residence when making safety assessments, and thus perceptions of campus or adjacent areas are not strongly influenced by prior residency experiences.

\section{Limitations}

The results of this study are affected by a few important limitations that should be noted. First, because this study is cross-section in design, we cannot definitely say if the differences in student safety perceptions by their current residence are caused by living in these places, or if differences in safety perceptions affect a college woman's choice of where to live. It is possible that students who are less concerned with safety choose to live off-campus, since they also appear to be more likely to engage in risk behaviors such as alcohol use. This, in turn, may contribute to higher rates of victimization. Though we examined a number of personal background variables which may affect choice of living arrangements (e.g., race, relationship status), it is always possible that some other factor not measured influences both a woman's

choice of residence and perception of safety. Overall, a slight majority of students (55.1\%) felt as 
safe or safer at the university compared to their previous residence, and regardless of whether or not they lived on-campus, and most students expressed greater concern for safety off-campus than on-campus.

Second, most dependent variables in this study were ultimately reduced to binary variables because ordinal regression assumptions were not met (e.g., number of cases in each cell for ordinal regression). Recoding key dependent variables to binary measures may have prevented us from detecting significant differences in our multivariate models that are suggested by bivariate comparisons, particularly between place of residence and fear of crime measures. Future research on fear of crime should consider utilizing scale rather than ordinal measures in order to allow for a wider range of analytic techniques (e.g., Lee \& Hilinski-Rosick, forthcoming).

\section{$\underline{\text { Conclusion }}$}

This study provided an exploratory look at how residency experiences affect college women's perceptions of safety, fear of victimization, and precautionary behaviors. This study distinguished between a proximal effect, a student's current residence, and a distal effect from a student's prior residency. This study consistently found that students living on-campus and students living off-campus at one large, state university had significantly different levels of concern for safety and engaged in different types of precautionary behaviors. The results of this study also suggest that students from smaller or larger communities of prior residency have similar experiences safety on campus. However, a student's current residency either on-campus or off-campus significantly shapes concern for safety in both on-campus and off-campus places, 
and changes the types of precautionary behaviors taken out of concern for safety. Owing to the overall low levels of fear of any crime-offender combination and to the strong effects of "the shadow of sexual assault" and prior victimization, place of residence did not impact fear of specific forms of victimization by specific offenders. These findings suggest that college administrators should pay particular attention to whether or not female students live on- or offcampus when targeting safety information to improve overall perceptions of safety among students. 


\section{References}

Altheide, D. L. (2002). Creating fear: News and the construction of crisis. New York: Gruyter.

Amar, A. F., Bess, R., \& Stockbridge, J. (2010). Lessons from families and communities about interpersonal violence, victimization, and seeking help. Journal of Forensic Nursing, 6(3), 110-120.

Benbenishty, R., \& Astor, R. A. (2005). School violence in context: Culture, neighborhood, family, school, and gender. New York: Oxford University Press.

Buhi, E. R., Clayton, H., \& Surrency, H. H. (2009). Stalking Victimization Among College Women and Subsequent Help-Seeking Behaviors. Journal of American College Health, 57(4), 419-426.

Campbell, J., Campbell, D. W., Gary, F., Nedd, D., Price-Lea, P., Sharps, P. W., \& Smith, C. (2008). African American women's responses to intimate partner violence: An examination of cultural context. Journal of Aggression, Maltreatment \& Trauma, 16(3), 277-295.

Clauss-Ehlers, C. S. (2008). Sociocultural factors, resilience, and coping: Support for a culturally sensitive measure of resilience. Journal of Applied Developmental Psychology, 29(3), 197-212.

Donnermeyer, J. F., \& Mullen, R. E. (1987). Use of neighbors for crime prevention: Evidence from a state-wide rural victim study. Journal of the Community Development Society, 18(1), 15-29.

Duhart, D. T. (2000). Urban, suburban, and rural victimization, 1993-98. Washington, DC: Bureau of Justice Statistics. 
El-Khoury, M., Dutton, M. A., Goodman, L. A., Engel, L., Belameric, R., \& Murphy, M. (2004). Ethnic differences in battered women's formal help-seeking strategies: A focus on health, mental health, and spirituality. Cultural Diversity \& Ethnic Minority Psychology, 10, 383-393.

Ferraro, K. F. (1995). Fear of crime: Interpreting victimization risk. Albany, NY: SUNY Press.

Ferraro, K. F. (1996). Women's fear of victimization: Shadow of sexual assault? Social Forces, 75, 667-690.

Fisher, B. S., Cullen, F. T., \& Turner, M. G. (2002). Being Pursued: Stalking Victimization in a National Study of College Women. Criminology \& Public Policy, 1(2), 257-308.

Fisher, B. S., Daigle, L. E., \& Cullen, F. T. (2010). Unsafe in the ivory tower: The sexual victimization of college women. Thousand Oaks, CA: Sage.

Fisher, B. S., \& May, D. (2009). College students' crime-related fear on campus: Are fearprovoking cues gendered? Journal of Contemporary Criminal Justice, 25(3), 300-321.

Fisher, B. S., \& Nasar, J. L. (1995). Fear spots in relation to microlevel physical clues: Exploring the overlooked. Journal of Research in Crime and Delinquency, 32(2), 214-239.

Fisher, B. S., \& Sloan, J. J. (2003). Unraveling the fear of victimization among college women: Is the "shadow of sexual assault hypothesis" supported? Justice Quarterly, 20(3), 633659.

Fisher, B. S., Sloan, J. J., Cullen, F. T., \& Lu, C. (1998). Crime in the ivory tower: The level and sources of student victimization. Criminology, 671-710.

Hickman, S. E., \& Muehlenhard, C. L. (1997). College Women's Fears and Precautionary Behaviors Relating to Acquaintance Rape and Stranger Rape. Psychology of Women Quarterly, 21(4), 527-547. 
Hilinski, C. M. (2009). Fear of crime among college students: A test of the shadow of sexual assault hypothesis. American Journal of Criminal Justice, 34(1-2), 84-102.

Hilinski, C. M. (2010). The role of victim-offender relationships in predicting fear of rape among college women. Criminal Justice Studies: A Critical Journal of Crime, Law \& Society, 23(2), 147-162.

Hughes, P. P., Marshall, D., \& Sherrill, C. (2003). Multidimensional Analysis of Fear and Confidence of University Women Relating to Crimes and Dangerous Situations. Journal of Interpersonal Violence, 18(1), 33-49.

Hunter, L. M., Krannich, R. S., \& Smith, M. D. (2002). Rural migration, rapid growth, and fear of crime. Rural Sociology, 67(1), 71-89.

Jackson, J. (2004). Experience and expression: Social and cultural significance in the fear of crime. British Journal of Criminology, 44(6), 946-966.

Jordan, C. E., Wilcox, P., \& Pritchard, A. J. (2007). Stalking acknowledgement and reporting among college women experiencing intrusive behaviors: Implications for the emergence of a “classic stalking case”. Journal of Criminal Justice, 35(5), 556-569.

Keane, C. (1998). Evaluating the influence of fear of crime as an environmental mobility restrictor on women's routine activities. Environment \& Behavior, 30(1), 60.

Kennedy, L. W., \& Krahn, H. (1984). Rural-urban origin and fear of crime: The case for "rural baggage". Rural Sociology, 49(2), 247-260.

Kruger, D. J., Hutchinson, P., Monroe, M. G., Reischl, T., \& Morrel-Samuels, S. (2007). Assault injury rates, social capital, and fear of neighborhood crime. Journal of Community Psychology, 35(4), 483-498. 
LaGrange, R. L., \& Ferraro, K. F. (1989). Assessing age and gender differences in perceived risk and fear of crime. Criminology, 27, 697-719.

LaGrange, R. L., Ferraro, K. F., \& Supancic, M. (1992). Perceived risk and fear of crime: Role of social and physical incivilities. Journal of Research in Crime \& Delinquency, 29, 311334.

Lane, J., Gover, A. R., \& Dahod, S. (2009). Fear of violent crime among men and women on campus: The impact of perceived risk and fear of sexual assault. Violence and Victims, 24(2), 172-192.

Lee, D., \& Hilinski-Rosick, C. (forthcoming). The Role of Lifestyle and Personal Characteristics on Fear of Victimization among University Students. American Journal of Criminal Justice, 1-22.

Leipert, B. D., \& George, J. A. (2008). Determinants of Rural Women's Health: A Qualitative Study in Southwest Ontario. The Journal of Rural Health, 24(2), 210-218.

Lipsky, S., \& Caetano, P. (2007). The Role of Race/Ethnicity in the Relationship Between Emergency Department Use and Intimate Partner Violence: Findings From the 2002 National Survey on Drug Use and Health. American Journal of Public Health, 97(12), 2246-2252.

Lipsky, S., Caetano, R., Field, C. A., \& Larkin, G. L. (2006). The Role of Intimate Partner Violence, Race, and Ethnicity in Help-Seeking Behaviors. Ethnicity \& Health, 11(1), 81100.

Logan, T., Walker, R., Jordan, C. E., \& Leukefeld, C. G. (2007). Women and victimization: Contributing factors, intervetions, and implications. Washington, D.C.: American Psychological Association. 
May, D. C. (2001). The effect of fear of sexual victimization on adolescent fear of crime. Sociological Spectrum, 21, 141-174.

May, D. C., \& Dunaway, G. R. (2000). Predictors of fear of crime among adolescents. Sociological Spectrum, 20, 149-168.

McGarrell, E. F., Giacomazzi, A., \& Thurman, Q. C. (1997). Neighborhood disorder, integration, and fear of crime. Justice Quarterly, 14, 479-500.

Melde, C. (2009). Lifestyle, rational choice, and adolescent fear: A test of a risk-assessment framework. Criminology, 47, 781-811.

Nicolaidis, C., Timmons, V., Thomas, M. J., Waters, A. S., Wahab, S., Mejia, A., \& Mitchell, S. R. (2010). "You Don't Go Tell White People Nothing": African American Women's Perspectives on the Influence of Violence and Race on Depression and Depression Care. American Journal of Public Health, 100(8), 1470-1476.

Pain, R. (2000). Place, social relations and the fear of crime: A review. Progress in Human Geography, 24(3), 365-387.

Palarea, R., Zona, M., Lane, J., \& Langhinrichsen-Rohling, J. (1999). The dangerous nature of stalking: Threats, violence and associated risk factors. Behavioral Sciences and the Law, 17, 269-283.

Phillips, L., Quirk, R., Rosenfeld, B., \& O’Connor, M. (2004). Is it Stalking? Perceptions of stalking among college undergraduates. Criminal Justice and Behavior, 31(1), 73-96.

Rader, N., \& Cossman, J. (2011). Gender Differences in U.S. College Students' Fear for Others. Sex Roles, 64(7/8), 568-581.

Ruback, R. B., \& Menard, K. S. (2001). Rural-Urban Differences in Sexual Victimization and Reporting. Criminal Justice and Behavior, 28(2), 131-155. 
Sabina, C., Cuevas, C. A., \& Schally, J. L. (2011). Help-Seeking in a National Sample of Victimized Latino Women: The Influence of Victimization Types. Journal of Interpersonal Violence, In press.

Schafer, J. A., Huebner, B. M., \& Bynum, T. S. (2006). Fear of crime and criminal victimization: Gender-based contrasts. Journal of Criminal Justice, 34(3), 285-301.

Swartz, K., Reyns, B. W., Henson, B., \& Wilcox, P. (2011). Fear of in-school victimization: Contextual, gendered, and developmental considerations. Youth Violence and Juvenile Justice, 9, 59-78.

Taylor, R. B. (2001). Breaking away from broken windows: Baltimore neighborhoods and the nationwide fight against crime, grime, fear, and decline. Boulder, CO: Westview.

Tillyer, M. S., Fisher, B. S., \& Wilcox, P. (2011). The effects of school crime prevention on students' violent victimization, risk perception and fear of crime: A multilevel opportunity perspective. Justice Quarterly, 28, 249-277.

Tjaden, P., \& Thoennes, N. (1998). Prevalence, incidence, and consequences of violence against women: Findings from the national violence against women survey (`, Trans.). Washington, DC: National Institute of Justice.

Warr, M. (1984). Fear of victimization: Why are women and the elderly more afraid? Social Science Quarterly, 65, 681-702.

Warr, M. (1985). Fear of rape among urban women. Social Problems, 32, 238-250.

Warr, M. (2000). Fear of crime in the United States: Avenues for research and policy. In D. Duffee (Ed.), Measurement and analysis of crime and justice: Criminal Justice 2000 (pp. 451-489). Washington, DC: U.S. Department of Justice. 
Wilcox, P., Jordan, C. E., \& Pritchard, A. J. (2006). Fear of acquaintance versus stranger rape as a 'master status': towards the refinement of the 'shadow of sexual assault'. Violence and Victims, 23(3), 357-373.

Wilcox, P., Jordan, C. E., \& Pritchard, A. J. (2007). A multidimensional examination of campus safety: Issues confronting college women in the post-Clery era. Crime \& Delinquency, $53,219-254$.

Wilcox, P., Quisenberry, N., \& Jones, S. (2003). The built environment and community crime risk interpretation. Journal of Research in Crime \& Delinquency, 40(3), 322-345.

Wilcox Rountree, P., \& Land, K. C. (1996). Perceived risk versus fear of crime: Empirical evidence of conceptually distinct reactions in survey data. Social Forces, 74, 1353-1376.

Woolnough, A. D. (2009). Fear of crime on campus: Gender differences in use of self-protective behaviours at an urban university. Security Journal, 22(1), 40-55. 
Table 1. Bivariate comparison across place of residency.

\begin{tabular}{|c|c|c|c|c|c|c|c|}
\hline \multirow[b]{2}{*}{ Variable } & \multicolumn{3}{|c|}{ On-Campus (n=492) } & \multicolumn{3}{|c|}{ Off-Campus (n=583) } & \multirow[b]{2}{*}{ p-value } \\
\hline & $\bar{N}$ & $\begin{array}{l}\text { Mean } \\
\text { (s.d.) }\end{array}$ & Percent & $\overline{\mathrm{N}}$ & $\begin{array}{l}\text { Mean } \\
\text { (s.d.) }\end{array}$ & Percent & \\
\hline Age & 492 & $\begin{array}{l}19.21 \\
(1.07)\end{array}$ & - & 583 & $\begin{array}{l}22.41 \\
(5.18)\end{array}$ & - & $<.000$ \\
\hline White (non-Hispanic) & 391 & -- & $79.5 \%$ & 528 & -- & $90.6 \%$ & $<.000$ \\
\hline Romantically involved & 249 & -- & $50.7 \%$ & 383 & -- & $66.0 \%$ & $<.000$ \\
\hline Victimized at college & 164 & -- & $33.3 \%$ & 232 & -- & $39.8 \%$ & .017 \\
\hline $\begin{array}{l}\text { Sexual } \\
\text { known offender }\end{array}$ & $\begin{array}{l}85 \\
64\end{array}$ & -- & $\begin{array}{l}\mathbf{1 7 . 3 \%} \\
80.0 \%^{A}\end{array}$ & $\begin{array}{l}143 \\
103\end{array}$ & -- & $\begin{array}{l}\mathbf{2 4 . 5 \%} \\
74.1 \%\end{array}$ & $\begin{array}{l}.002 \\
.162\end{array}$ \\
\hline Physical & 52 & -- & $10.6 \%$ & 75 & -- & $12.8 \%$ & .145 \\
\hline known offender & 48 & & $94.1 \%{ }^{A}$ & 61 & & $81.3 \%{ }^{A}$ & .020 \\
\hline Stalking & 72 & -- & $14.6 \%$ & 102 & -- & $17.5 \%$ & .118 \\
\hline known offender & 37 & & $56.1 \%{ }^{A}$ & 59 & & $62.8 \%{ }^{A}$ & .197 \\
\hline $\begin{array}{l}\text { Uses alcohol once a } \\
\text { week or more }\end{array}$ & 120 & -- & $24.4 \%$ & 233 & -- & $40.0 \%$ & $<.000$ \\
\hline $\begin{array}{l}\text { Carry or keep } \\
\text { something for } \\
\text { protection }\end{array}$ & 222 & -- & $45.2 \%$ & 335 & -- & $57.7 \%$ & $<.000$ \\
\hline Academic class & 491 & -- & $99.8 \%$ & 582 & -- & $99.8 \%$ & \\
\hline Freshman & 267 & -- & $54.4 \%$ & 44 & -- & $7.6 \%$ & $<.000$ \\
\hline Sophomore & 129 & -- & $26.3 \%$ & 98 & -- & $16.8 \%$ & $<.000$ \\
\hline Junior & 59 & -- & $12.0 \%$ & 169 & -- & $29.0 \%$ & $<.000$ \\
\hline Senior & 36 & -- & $5.5 \%$ & 271 & -- & $46.6 \%$ & $<.000$ \\
\hline
\end{tabular}

Note: P-values calculated using two-proportion z-test, except for mean age which uses a t-test.

${ }^{A}$ Percent based on valid cases within victimization type. 
Table 2. Bivariate comparison across place of origin.

\begin{tabular}{|c|c|c|c|c|c|c|c|c|c|c|}
\hline \multirow[b]{2}{*}{ Variable } & \multicolumn{3}{|c|}{ Metro $(n=787)$} & \multicolumn{3}{|c|}{ Micropolitan $(n=164)$} & \multicolumn{3}{|c|}{ Noncore $(n=171)$} & \multirow[b]{2}{*}{$\begin{array}{l}\mathrm{p} \text {-value } \\
(\mathrm{df}=2)\end{array}$} \\
\hline & $\mathrm{N}$ & $\begin{array}{l}\text { Mean } \\
\text { (s.d.) }\end{array}$ & Percent & $\mathrm{N}$ & $\begin{array}{l}\text { Mean } \\
\text { (s.d.) }\end{array}$ & Percent & $\mathrm{N}$ & $\begin{array}{l}\text { Mean } \\
\text { (s.d.) }\end{array}$ & Percent & \\
\hline Age & 787 & $\begin{array}{l}20.83 \\
(4.11)\end{array}$ & - & 164 & $\begin{array}{l}21.18 \\
(4.13)\end{array}$ & - & 174 & $\begin{array}{l}21.13 \\
(4.19)\end{array}$ & -- & .472 \\
\hline White (non-Hispanic) & 660 & -- & $83.9 \%$ & 145 & -- & $87.9 \%$ & 158 & -- & $92.4 \%^{1}$ & .011 \\
\hline Romantically involved & 453 & -- & $57.6 \%$ & 103 & -- & $63.6 \%$ & 105 & -- & $62.1 \%$ & .261 \\
\hline Victimized at college & 298 & -- & $37.9 \%$ & 60 & -- & $36.6 \%$ & 53 & -- & $31.0 \%$ & .240 \\
\hline $\begin{array}{l}\text { Sexual } \\
\text { known offender }\end{array}$ & $\begin{array}{l}172 \\
125\end{array}$ & -- & $\begin{array}{l}21.9 \% \\
74.4 \%{ }^{A}\end{array}$ & $\begin{array}{l}36 \\
30\end{array}$ & -- & $\begin{array}{c}22.0 \% \\
90.9 \%^{A}\end{array}$ & $\begin{array}{l}29 \\
20\end{array}$ & -- & $\begin{array}{c}17.0 \% \\
71.4 \%^{A}\end{array}$ & $\begin{array}{l}.350 \\
.100\end{array}$ \\
\hline $\begin{array}{l}\text { Physical } \\
\text { known offender }\end{array}$ & $\begin{array}{l}98 \\
85\end{array}$ & -- & $\begin{array}{c}12.5 \% \\
88.5 \%^{A}\end{array}$ & $\begin{array}{l}13 \\
11\end{array}$ & -- & $\begin{array}{c}7.9 \% \\
78.6 \%\end{array}$ & $\begin{array}{l}20 \\
17\end{array}$ & -- & $\begin{array}{c}11.7 \% \\
85.0 \%^{A}\end{array}$ & $\begin{array}{l}.260 \\
.564\end{array}$ \\
\hline $\begin{array}{l}\text { Stalking } \\
\quad \text { known offender }\end{array}$ & $\begin{array}{c}130 \\
76\end{array}$ & -- & $\begin{array}{c}16.5 \% \\
63.3 \%{ }^{A}\end{array}$ & $\begin{array}{l}32 \\
13\end{array}$ & -- & $\begin{array}{c}19.4 \% \\
50.0 \%^{A}\end{array}$ & $\begin{array}{l}21 \\
12\end{array}$ & -- & $\begin{array}{c}12.4 \% \\
57.1 \%^{A}\end{array}$ & $\begin{array}{l}.210 \\
.427\end{array}$ \\
\hline $\begin{array}{l}\text { Uses alcohol once a } \\
\text { week or more }\end{array}$ & 274 & -- & $34.8 \%$ & 38 & -- & $23.0 \%^{1}$ & 47 & -- & $\underset{2}{27.6 \%}{ }^{1}$ & .005 \\
\hline $\begin{array}{l}\text { Carry or keep } \\
\text { something for } \\
\text { protection }\end{array}$ & 403 & -- & $51.2 \%$ & 86 & -- & $52.4 \%$ & 94 & -- & $55.0 \%$ & .665 \\
\hline Academic class & 787 & -- & $100.0 \%$ & 164 & -- & $100.0 \%$ & 171 & -- & $100.0 \%$ & .230 \\
\hline Freshman & 222 & -- & $28.2 \%$ & 44 & -- & $26.8 \%$ & 58 & -- & $33.9 \%$ & $(\mathrm{df}=6)$ \\
\hline Sophomore & 167 & -- & $21.2 \%$ & 34 & -- & $20.7 \%$ & 34 & -- & $19.9 \%$ & \\
\hline Junior & 181 & -- & $23.0 \%$ & 37 & -- & $22.6 \%$ & 24 & -- & $14.0 \%$ & \\
\hline Senior & 217 & -- & $27.5 \%$ & 49 & -- & $29.9 \%$ & 55 & -- & $32.2 \%$ & \\
\hline Lives off-campus & 403 & -- & $53.3 \%$ & 88 & -- & $55.7 \%$ & 92 & -- & $57.5 \%$ & .581 \\
\hline
\end{tabular}

Note: Proportions are calculated using a $\chi^{2}$ test with degrees of freedom as indicated.

${ }^{1}$ Significantly differs from Metro in a one-tailed Z-test at a=.05.

${ }^{2}$ Significantly differs from Micropolitan in a one-tailed Z-test at a=.05.

${ }^{A}$ Percent based on valid cases within victimization type. 
Table 3. Binary logistic regression models for concern for safety on-campus and in nearby off-campus areas.

\begin{tabular}{|c|c|c|c|c|c|c|}
\hline \multirow[b]{2}{*}{ Variable } & \multicolumn{3}{|c|}{ "Concern for safety on-campus } & \multicolumn{3}{|c|}{ Concern for safety off-campus } \\
\hline & $\mathrm{B}$ & S.E. & Odds Ratio & $\mathrm{B}$ & S.E. & Odds Ratio \\
\hline \multicolumn{7}{|l|}{ Place of Residence } \\
\hline Lives on-campus & -.147 & .300 & .863 & $.556 * *$ & 191 & 1.743 \\
\hline \multicolumn{7}{|l|}{ Place of Origin } \\
\hline Micropolitan place of origin & .073 & .340 & 1.076 & -.194 & .208 & .823 \\
\hline Noncore place of origin & .335 & .392 & 1.398 & -.241 & .208 & .786 \\
\hline \multicolumn{7}{|l|}{ Control Variables } \\
\hline Non-white race/ethnicity & -.328 & .328 & .720 & -.037 & .226 & .964 \\
\hline Currently romantically involved & -.007 & .245 & .993 & -.177 & .154 & .837 \\
\hline Uses alcohol 1x week or more & .080 & .262 & 1.083 & -.022 & .161 & .978 \\
\hline $\begin{array}{l}\text { Experienced victimization in } \\
\text { college }\end{array}$ & $-.695 * *$ & .242 & .499 & $-.747 * *$ & .151 & .474 \\
\hline Sophomore standing & -.229 & .391 & .795 & $-.518 *$ & .230 & .596 \\
\hline Junior standing & $-.963 *$ & .379 & .382 & -.452 & .248 & .637 \\
\hline Senior standing & -.442 & .409 & .643 & -.070 & .252 & .933 \\
\hline Constant & 3.298 & .440 & 27.061 & 1.640 & .273 & 5.154 \\
\hline
\end{tabular}

${ }^{*} \mathrm{p}<.05, * * \mathrm{p}<.01$ 
Table 4. Binary logistic regression models for fear of specific victimization-offender combinations (1=somewhat or very worried).

\begin{tabular}{|c|c|c|c|c|c|c|c|c|c|}
\hline \multirow[b]{2}{*}{ Variable } & \multicolumn{3}{|c|}{$\begin{array}{l}\text { Fear of Stalking by Known } \\
\text { Person }\end{array}$} & \multicolumn{3}{|c|}{ Fear of Stalking by Stranger } & \multicolumn{3}{|c|}{$\begin{array}{l}\text { Fear of Sexual Assault by a } \\
\text { Known Person }\end{array}$} \\
\hline & $\mathrm{B}$ & S.E. & $\begin{array}{l}\text { Odds } \\
\text { Ratio }\end{array}$ & B & S.E. & $\begin{array}{l}\text { Odds } \\
\text { Ratio }\end{array}$ & B & S.E. & $\begin{array}{l}\text { Odds } \\
\text { Ratio }\end{array}$ \\
\hline Place of Residence & & & & & & & & & \\
\hline $\begin{array}{l}\text { Lives on-campus } \\
\text { Place of Oriqin }\end{array}$ & .338 & .293 & 1.403 & .046 & .215 & 1.047 & .164 & .244 & 1.178 \\
\hline Micropolitan place of origin & -.064 & .327 & .938 & .277 & .232 & 1.320 & -.283 & .296 & .754 \\
\hline Noncore place of origin & .097 & .317 & 1.102 & -.034 & .242 & .967 & -.076 & .282 & .927 \\
\hline Control Variables & & & & & & & & & \\
\hline Non-white race/ethnicity & $.693^{*}$ & .277 & 2.000 & $.667 * *$ & .220 & 1.949 & .418 & .260 & 1.519 \\
\hline $\begin{array}{l}\text { Currently romantically } \\
\text { involved }\end{array}$ & .116 & .228 & .891 & -.013 & .170 & .987 & -.092 & .193 & .912 \\
\hline Uses alcohol 1x week or more & -.114 & .248 & .893 & -.086 & .184 & .918 & .370 & .203 & 1.448 \\
\hline $\begin{array}{l}\text { Experienced victimization in } \\
\text { college }\end{array}$ & $.815^{* *}$ & .227 & 2.259 & .332 & .172 & 1.394 & $.923 * *$ & .194 & 2.518 \\
\hline $\begin{array}{l}\text { High fear of stranger sexual } \\
\text { assault }\end{array}$ & $\begin{array}{l}1.248 * \\
*\end{array}$ & .310 & 3.484 & $\begin{array}{l}1.697^{*} \\
*\end{array}$ & .237 & 5.459 & -- & -- & -- \\
\hline Sophomore standing & -.189 & .354 & .828 & .150 & .273 & 1.162 & .143 & .266 & 1.153 \\
\hline Junior standing & -.122 & .377 & .885 & -.031 & .277 & .970 & -.236 & .313 & .790 \\
\hline Senior standing & -.531 & .230 & .588 & -.232 & .172 & .793 & -.381 & .317 & .683 \\
\hline Constant & -3.447 & .424 & .032 & -2.504 & .312 & .082 & -2.423 & .336 & .089 \\
\hline
\end{tabular}

$* \mathrm{p}<.05, * * \mathrm{p}<.01$ 
Table 4a. Binary logistic regression models for fear of specific victimization-offender combinations (1=somewhat or very worried).

\begin{tabular}{|c|c|c|c|c|c|c|c|c|c|}
\hline \multirow[b]{2}{*}{ Variable } & \multicolumn{3}{|c|}{$\begin{array}{l}\text { Fear of Sexual Assault by } \\
\text { Stranger }\end{array}$} & \multicolumn{3}{|c|}{$\begin{array}{l}\text { Fear of Physical Assault by } \\
\text { Known Person }\end{array}$} & \multicolumn{3}{|c|}{$\begin{array}{l}\text { Fear of Physical Assault by } \\
\text { Stranger }\end{array}$} \\
\hline & B & S.E. & $\begin{array}{l}\text { Odds } \\
\text { Ratio }\end{array}$ & B & S.E. & $\begin{array}{l}\text { Odds } \\
\text { Ratio }\end{array}$ & B & S.E. & $\begin{array}{l}\text { Odds } \\
\text { Ratio }\end{array}$ \\
\hline \multicolumn{10}{|l|}{ Place of Residence } \\
\hline Lives on-campus & -.201 & .163 & .818 & .600 & .358 & 1.821 & -.019 & .213 & .981 \\
\hline \multicolumn{10}{|l|}{ Place of Origin } \\
\hline Micropolitan place of origin & -.263 & .186 & .769 & -.598 & .481 & .567 & -.302 & .240 & .740 \\
\hline Noncore place of origin & .026 & .181 & 1.026 & .021 & .390 & 1.021 & .048 & .233 & 1.050 \\
\hline \multicolumn{10}{|l|}{ Control Variables } \\
\hline Non-white race/ethnicity & .191 & .183 & 1.211 & $.716 *$ & .344 & 2.046 & -.063 & .235 & .939 \\
\hline $\begin{array}{l}\text { Currently romantically } \\
\text { involved }\end{array}$ & .050 & .131 & 1.052 & -.057 & .281 & .945 & .222 & .169 & 1.249 \\
\hline Uses alcohol $1 \mathrm{x}$ week or more & .044 & .139 & 1.045 & .039 & .305 & 1.040 & -.247 & .181 & .781 \\
\hline $\begin{array}{l}\text { Experienced victimization in } \\
\text { college }\end{array}$ & $.446 * *$ & .133 & 1.563 & $.707 *$ & .282 & 2.029 & .127 & .171 & 1.135 \\
\hline $\begin{array}{l}\text { High fear of stranger sexual } \\
\text { assault }\end{array}$ & -- & -- & -- & $\begin{array}{l}1.770 * \\
*\end{array}$ & .375 & 5.870 & $\begin{array}{l}2.897 * \\
*\end{array}$ & .241 & 18.126 \\
\hline Sophomore standing & .125 & .186 & 1.133 & .537 & .456 & 1.711 & $.513^{*}$ & .273 & 1.670 \\
\hline Junior standing & -.181 & .207 & .834 & .357 & .471 & 1.429 & .211 & .271 & 1.235 \\
\hline Senior standing & -.217 & .207 & .805 & .133 & .321 & 1.142 & .314 & .167 & 1.369 \\
\hline Constant & -.458 & .219 & .633 & -4.763 & .569 & .009 & -2.390 & .309 & .092 \\
\hline
\end{tabular}

$* \mathrm{p}<.05, * * \mathrm{p}<.01$ 
Table 5. Binary logistic regression models for engaging in precautionary behaviors.

\begin{tabular}{|c|c|c|c|c|c|c|}
\hline \multirow[b]{2}{*}{ Variable } & \multicolumn{3}{|c|}{$\begin{array}{l}\text { Carrying/keeping an item for } \\
\text { protection }\end{array}$} & \multicolumn{3}{|c|}{ Avoiding places on campus } \\
\hline & $\mathrm{B}$ & S.E. & Odds Ratio & $\mathrm{B}$ & S.E. & Odds Ratio \\
\hline \multicolumn{7}{|l|}{ Place of Residence } \\
\hline Lives on-campus & $-.356^{*}$ & .163 & .700 & $.872 * *$ & .217 & 2.391 \\
\hline \multicolumn{7}{|l|}{ Place of Origin } \\
\hline Micropolitan place of origin & -.012 & .181 & .989 & .241 & .242 & 1.272 \\
\hline Noncore place of origin & .152 & .181 & 1.164 & .005 & .227 & 1.005 \\
\hline \multicolumn{7}{|l|}{ Control Variables } \\
\hline Non-white race/ethnicity & -.168 & .184 & .845 & -.239 & .232 & .788 \\
\hline Currently romantically involved & $.396 * *$ & .130 & 1.486 & -.242 & .169 & .785 \\
\hline Uses alcohol 1x week or more & -.222 & .140 & .801 & -.157 & .176 & .855 \\
\hline $\begin{array}{l}\text { Experienced victimization in } \\
\text { college }\end{array}$ & .065 & .136 & 1.067 & .054 & .179 & 1.055 \\
\hline $\begin{array}{l}\text { High fear of stranger sexual } \\
\text { assault }\end{array}$ & $.389 * *$ & .187 & 1.476 & $.660 * *$ & .244 & 1.935 \\
\hline Concern for safety on-campus & .090 & .207 & 1.094 & $.582 * *$ & .273 & 1.789 \\
\hline Concern for safety off-campus & .043 & .207 & 1.044 & $.538 * *$ & .264 & 1.712 \\
\hline Sophomore standing & -.081 & .134 & .922 & .285 & .183 & 1.330 \\
\hline Junior standing & .244 & .123 & 1.276 & $.706 * *$ & .164 & 2.026 \\
\hline Senior standing & .009 & .114 & 1.009 & $.534^{*}$ & .150 & 1.705 \\
\hline Constant & .000 & .315 & 1.000 & -.827 & .406 & .437 \\
\hline
\end{tabular}

$* \mathrm{p}<.05, * * \mathrm{p}<.01$ 
Figure 1. Mean fear of crime by crime type, victim-offender relationship, and place of residence.

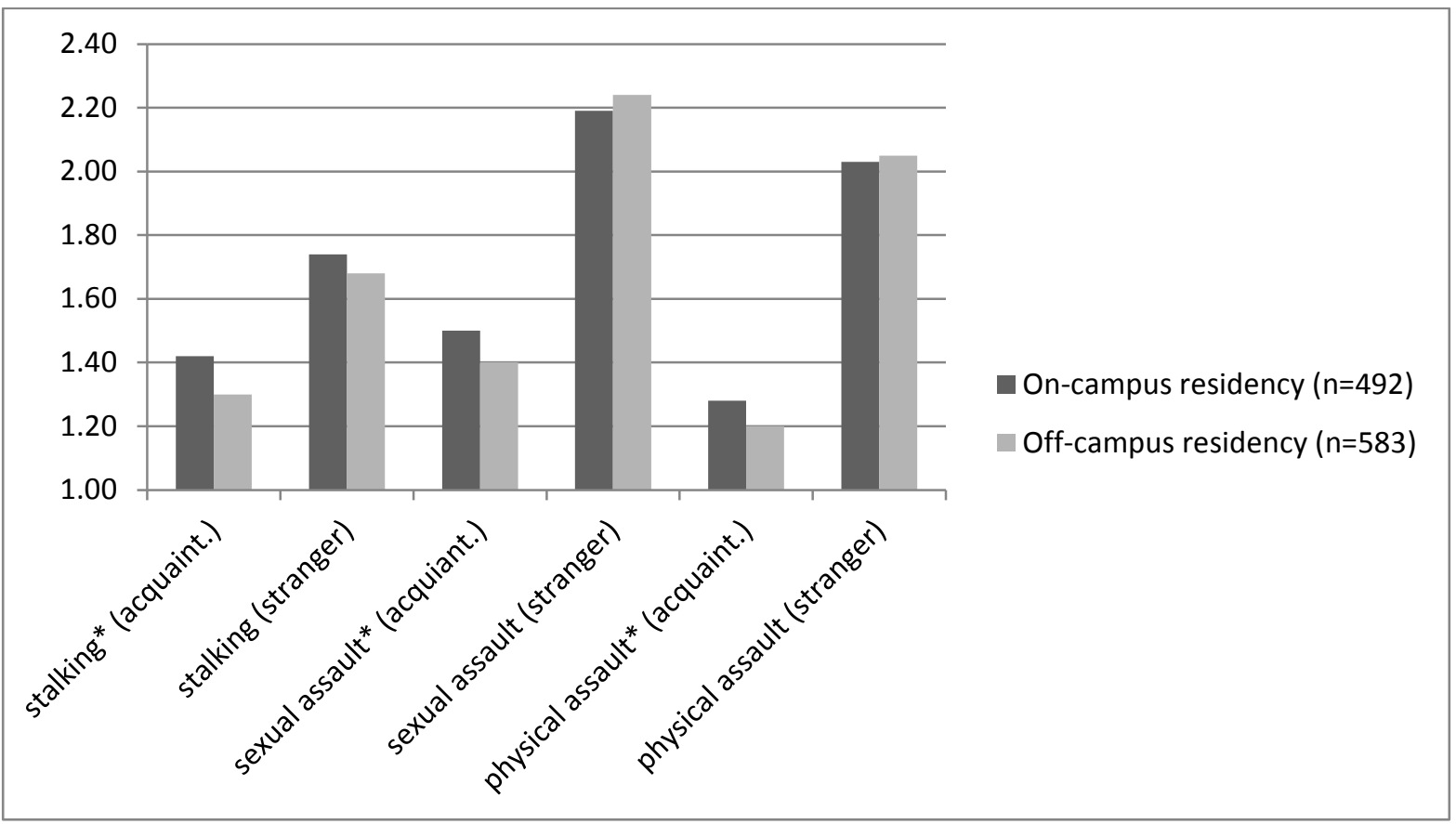

*Difference between place of residence within crime type and victim/offender relationship is significant at alpha $=.05$.

Figure 2. Mean fear of crime by crime type, victim-offender relationship, and place of origin. 


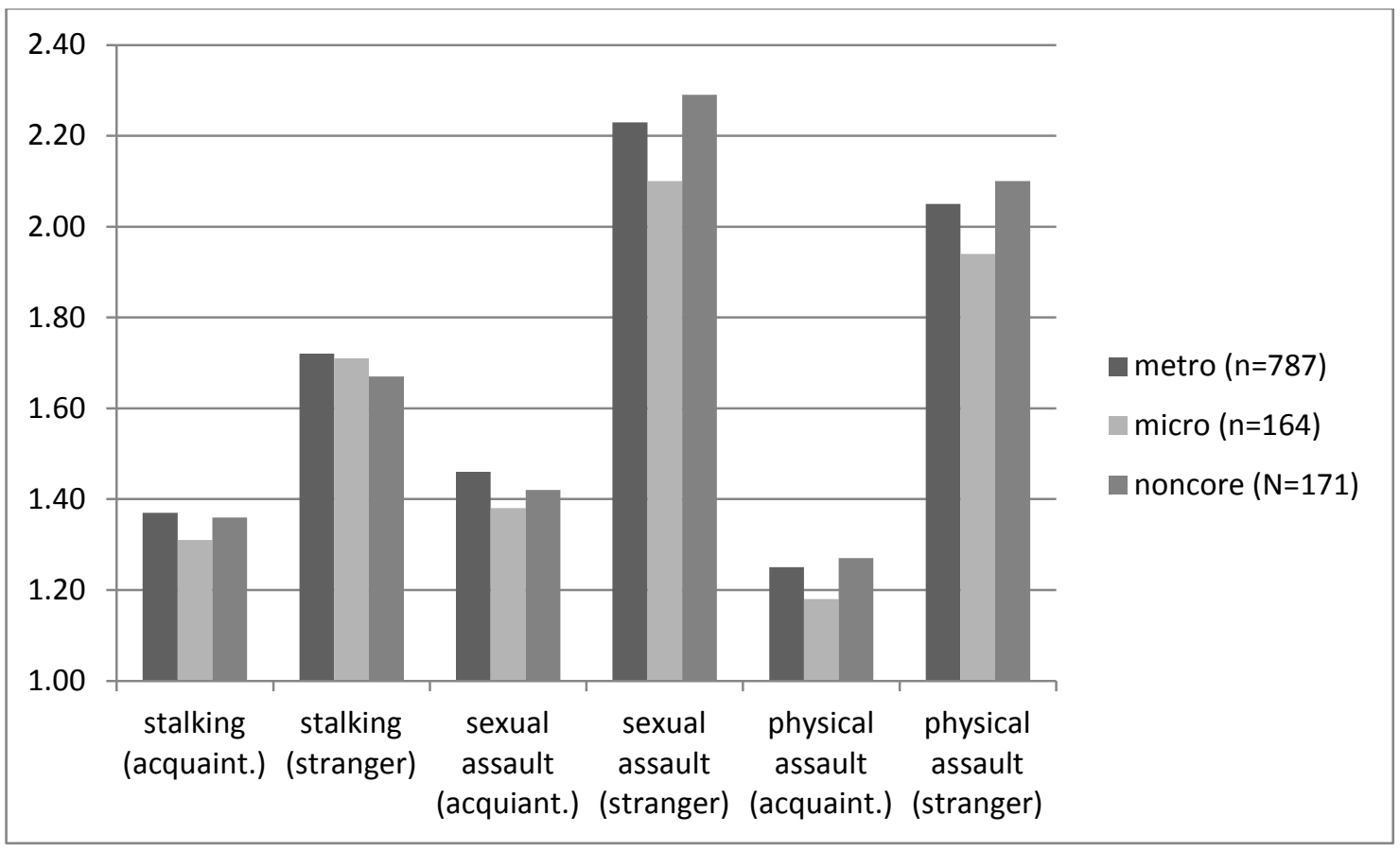

Note: No significant differences by place of origin within any crime type and victim/offender relationship comparisons. 